\title{
Bibliografi Penelitian Akuntansi Pemerintahan di Indonesia
}

\author{
Dedi Rusdi, Edy Suprianto* \\ Universitas Islam Sultan Agung Semarang, Indonesia
}

OPEN ACCESS

ISSN 2548-3501 (online)

ISSN 2548-3501 (online)

Edited by:

Wiwit Hariyanto

Correspondence

edy_2806@yahoo.co.id

Received: 1 September 2021

Accepted: 24 January 2022

Published: 31 January 2022

Citation:Rusdi dan Suprianto (2022) Bibliograpi Penelitian

Akuntansi Pemerintahan di

Indonesia
This study aims to describe the development of government accounting research in Indonesia from 9 accredited journals in Indonesia indexed by Sinta 2. The sample obtained from 2011 to 2021 obtained 45 articles discussing government accounting. Based on the results of the analysis, the majority of research on government accounting in Indonesia is published in JAAI and JAB respectively by $20 \%$, while MRAAI is $11 \%$ and JAMAL is $16 \%$. Of the 45 articles obtained, 11 articles are qualitative method research, while 34 articles are research using quantitative methods. In qualitative research the method of descriptive analysis or case studies is the most widely used, while in quantitative research the most widely used method is regression analysis. This study provides historical evidence of the development of research on government accounting in Indonesia, so that it can be used as literature review material for further research that will conduct the same research in Indonesia.

Keywords: Government Accounting, accredited journal, Research Method

Penelitian ini mencoba mendeskripsikan perkembangan penelitian akuntansi pemerintahan di Indonesia yang dari 9 jurnal akreditasi di indonesia yang terindeks Sinta 2. Sampel yang diperoleh dari tahun 2012 sampai dengan tahun 2021 diperoleh 45 artikel yang membahas tentang akuntansi pemerintahan. Berdasarkan pada hasil analisis, mayoritas penelitian tentang akuntansi pemerintahan di indonesia diterbitkan di JAAI dan JAB masing-masing sebesar 20\%, sementara MRAAI $11 \%$ dan JAMAL $16 \%$. Dari 45 artikel yang diperoleh, 11 artikel adalah penelitian metode kualitatif, sedangkan penelitian yang menggunakan metode kuantitatif sebanyak 34 artikel. Pada penelitian kualitatif metode analisis deskriptif atau studi kasus yang paling banyak digunakan, sedangkan pada penelitian kuantitatif metode yang paling banyak digunakan adalah analisis regresi. Penelitian ini memberikan bukti sejarah perkembangan penelitian tentang akuntansi pemerintah di Indonesia, sehingga dapat menjadi bahan literature review untuk penelitian selanjutnya yang akan melakukan penelitian yang sama di Indonesia.

Keywords: Akuntansi Pemerintah, Jurnal Akreditasi, Metode Penelitian 


\section{PENDAHULUAN}

Perkembangan akuntansi sektor publik khususnya sektor pemerintah saat ini cukup signifikan setelah diterbitkan Peraturan Pemerintah (PP) No 71 Tahun 2010 tentang Standar Akuntansi Pemerintah. Dengan munculnya PP ini membawa dampak yang cukup signifikan terhadap kualitas laporan keuangan pemerintah baik pusat maupun daerah. Hal ini terbukti dengan hasil audit Badan Pemeriksa Keuangan (BPK) terhadap laporan keuangan pemerintah daerah sebagian besar memperoleh opini wajar tanpa pengecualian. Hal ini yang memberikan motivasi kepada para peneliti di Indonesia untuk mengkaji tentang kualitas laporan keuangan pemerintah di Indonesia. Hal ini memberikan memotivasi juga kepada penulis untuk memotret perkembangan penelitian tentang akuntansi pemerintahan di Indonesia selama 10 tahun terakhir.

Dengan mendasarkan pada pendekatan kualitatif dengan metode meta-analisis yang dikembangkan oleh Hesford dkk. (2007), penulis mencoba mengevaluasi beberapa penelitian tentang akuntansi pemerintah di Indonesia. Adi dan Nugraheni (2020) telah membuat meta analisis tentang kinerja keuangan pemerintah yang telah terbit pada jurnal Media Riset Akuntansi, Auditing dan Informasi. Namun, ada beberapa kelemahan pada artikel tersebut. Pertama, penelitian tersebut hanya berfokus pada kinerja keuangan saja, kenyataanya masih banyak penelitian tentang kinerja pemerintah misalnya kinerja laporan keuangan, kinerja manajerial dan lain-lain. Kedua, penelitian tersebut menggunakan sampel artikel yang diperoleh dari tesis dan skripsi yang masih perlu pengkajian lebih mendalam. Ketiga, tahun penelitian dari 2006 sampai dengan 2016, padahal masih banyak penelitian selama 5 tahun terakhir. Hal ini juga mendorong penelitian ini untuk melengkapi penelitian sebelumnya.

Kontribusi penelitian ini pertama, memberikan bukti sejarah perkembangan penelitian tentang akuntansi pemerintah di Indonesia, sehingga dapat menjadi bahan literature review untuk penelitian selanjutnya yang akan melakukan penelitian yang sama di Indonesia. Kedua, artikel ini memberikan memberikan petunjuk kepada penelitian selanjutnya yang mungkin dapat dilakukan. Ketiga, artikel ini memberikan pandangan kepada peneliti selanjutnya untuk dapat mengevaluasi dan menganalisis lebih lanjut beberapa variabel, topik atau metode penelitian yang masih jarang diteliti di Indonesia

\section{METODE}

Pendekatan dalam penelitian ini mereplikasi pendekatan yang dilakukan oleh Hesford dkk. (2007). Ada beberapa kriteria yang kami tetapkan pertama, artikel yang dipilih adalah artikel yang terbit pada jurnal terakreditasi minimal sinta 2, karena artikel pada jurnal ini telah direview dan dikaji lebih mendalam oleh pakar yang terkait sehingga layak untuk terbit. Jurnal yang telah terakreditasi ini mendasarkan pada surat keputusan Menteri Riset dan Teknologi No 200/M/KPT/2020 tentang hasil evaluasi akreditasi jurnal ilmiah tahun 2020. Penelitian ini hanya berfokus pada bukti empiris yang ada di Indonesia. Kedua, jurnal yang dipilih adalah jurnal yang terbit secara online pada tahun 2011 sampai dengan 2021. Tahun ini dipilih karena untuk melihat sejarah penelitian akuntansi pemerintah lebih update dan rentang waktu lebih panjang. Ketiga, kata kuncinya artikel adalah akuntansi pemerintah yang meliputi banyak hal misalnya kinerja keuangan, kinerja anggaran kinerja manajerial dan kinerja laporan keuangan

\section{Populasi dan Sampel}

Populasi dalam penelitian ini adalah seluruh artikel yang diterbitkan di jurnal Indonesia. Sampel diperoleh dengan menggunakan purposive sampling dengan kriteria yang telah dijelaskan di bab metode. Berdasarkan teknik pengambilan sampel, diperoleh 9 jurnal yang telah menerbitkan artikel tentang akuntansi pemerintah. Nama-nama jurnal tersebut adalah Jurnal Akuntansi \& Auditing Indonesia (JAAI) Universitas Islam Indonesia, Jurnal Integritas (I), Jurnal Akuntansi \& Bisnis (JAB) Universitas Negeri Surakarta, Journal Trikonometri (JK), Jurnal Riset Akuntansi dan Keuangan Indonesia (RAKI), jurnal Media Riset Akuntansi, Auditing dan Informasi (MRAAI), jurnal Tata Kelola dan Akuntabilitas Keuangan Negara (TAKN), jurnal Dinamika Akuntansi (JDA), jurnal Multiparadigma (JAMAL). Daftar artikel yang menjadi sampel dalam penelitian ini ada di table 1 .

\section{[Table 1. about here]}

Berdasarkan pada kriteria yang telah ditetapkan di atas maka diperoleh 45 artikel yang terbit pada 9 jurnal terakreditasi minimal sinta 2. Pada Table 2 tentang deskripsi sampel di bawah dapat dilihat bahwa secara total (dari tahun 2012 s/d 2021), ada dua jurnal yang mendominasi penelitian tentang akuntansi pemerintah yaitu JAAI dan JAB sebesar 20\%, sementara MRAAI $11 \%$ dan JAMAL $16 \%$.

\section{[Table 2. about here]}

\section{HASIL DAN PEMBAHASAN}

Pada hasil dan pembahasan ini akan dimulai dari klasifikasi artikel berdasarkan pada topik penelitian dan metode penelitian. Selanjutnya akan dibahas di masingmasing klasifikasi. Berdasarkan hasil penelusuran pada artikel yang menjadi sampel, definisi akuntansi pemerintah dalam penelitian ini meliputi kinerja keuangan pemerintah baik pemerintah pusat dan daerah maupun pemerintah desa, kinerja laporan keuangan pemerintah termasuk di dalamnya adalah hasil audit BPK, Kinerja anggaran baik belanja maupun pendapatan, serta Kinerja Manajerial pemerintah termasuk di dalamnya korupsi fraud dan lain-lain.

\section{Klasifikasi berdasarkan Topik Pembahasan}

Pengklasifikasian artikel tentang akuntansi pemerintah yang pertama adalah berdasarkan pada topik penelitian. Pengklasifikasian ini dibedakan menjadi 2 yaitu anteseden (variabel independen) dan konsekuensi (variabel dependen). Dalam hal ini akuntansi pemerintah bisa menjadi variabel independen yang mempengaruhi variabel lainnya.

Table 3, menunjukkan bahwa ada 3 (tiga) variabel akuntansi pemerintah (ditebalkan) sebagai variabel independen yaitu variabel kualitas pengelolaan anggaran sebanyak 5 artikel, variabel opini audit sebanyak 1 artikel dan kinerja pemda sebanyak 3 artikel. Variabel akuntansi pemerintah tersebut menjadi variabel independen, karena 
menggunakan analisis kualitatif atau studi kasus pada pemda tertentu. Misalnya analisis pengelolaan anggaran pada pemerintah daerah tertentu atau analisis laporan keuangan pada pemerintah daerah tertentu. Dari Table 3 di atas juga dapat dilihat bahwa variabel independen yang mempengaruhi akuntansi pemerintah yang paling banyak diteliti adalah variabel karakteristik keuangan seperti belanja, pendapatan, hutang, kekayaan, serta rasio-rasio keuangan lainya. Variabel ini menempati posisi yang paling banyak diteliti sebanyak 14 artikel atau $15 \%$ dari sampel penelitian. Variabel independen lainya yang banyak diteliti adalah variabel sistem pengendalian internal dan komitmen organisasi masing-masing sebanyak $10 \%$ dan $9 \%$. Variabel lainya adalah regulasi, faktor ekonomi, karakteristik legislative, faktor politik, standar akuntansi Pemerintah (SAP), sistem informasi, umur pemerintah dan kepala daerah.

\section{[Table 3. about here]}

Jika melihat potret penelitian sebelumnya, faktorfaktor yang mempengaruhi akuntansi pemerintah telah banyak dilakukan oleh beberapa peneliti. Penelitian selanjutnya masih memiliki kemungkinan untuk mengembangkan variabel-variabel di atas yang masih jarang diteliti khususnya faktor ekonomi, karakteristik legislatif, faktor politik, Standar Akuntansi Pemerintah (SAP), sistem informasi, umur pemerintah dan kepala daerah. Namun masih ada kemungkinan peluang faktor lain yang belum menjadi perhatian penelitian sebelumnya, misalnya dampak faktor sosial seperti dampak covid-19, pengangguran, budaya antar daerah dan lain-lain. Penelitian selanjutnya juga dapat lebih berfokus pada karakteristik kepala daerah seperti pengalaman, staf yang dimiliki, gender, dan lain-lain. Christiaens dan Van Peteghem (2007), Christiaens dkk (2015), Harun dan Robinson (2010) menyatakan bahwa ada faktor eksternal seperti tekanan internasional dan krisis ekonomi yang mempengaruhi perkembangan akuntansi pemerintahan.

\section{[Table 4. about here]}

Tabel 4 di atas menjelaskan secara detail tentang variabel lain apa saja yang dibahas oleh peneliti. Melihat Table 4 di atas sangat menarik, baru ada 2 artikel saja yang membahas tentang variabel lain diantaranya adalah variabel transparansi dan akuntabilitas publik dan variabel fraud. Dengan kata lain bahwa masih sangat minim sekali penelitian yang membahas tentang bagaimana dampak akuntansi pemerintah terhadap kinerja keuangan pemerintah atau perekonomian secara umum. Seperti Christofzik (2019) yang meneliti dampak implementasi akuntansi akrual terhadap kebijakan fiskal. Variabel transparansi dan akuntabilitas publik sebagai variabel moderasi, sedangkan variabel fraud sebagai variabel intervening. Penelitian selanjutnya dapat mengembangkan model dari beberapa penelitian yang telah peneliti rangkum di dalam artikel ini. Model yang dapat dikembangkan bisa menjadi variabel moderasi maupun sebagai variabel intervening. Misalnya, apakah budaya atau gaya kepemimpinan kepala daerah dapat menjadi variabel moderasi dan lain-lain.

\section{Klasifikasi Artikel Berdasarkan Metode Penelitian}

Berdasarkan pada metode penelitian yang dilakukan untuk meneliti akuntansi pemerintah di Indonesia ada dua kelompok yaitu penelitian kuantitatif dan penelitian kualitatif. Jumlah artikel kedua kelompok secara rinci dapat dilihat pada $\underline{\text { Table } 5}$ dan Table 6 sebagai berikut:

\section{[Table 5. about here]}

Dari 45 artikel terdapat 11 artikel yang termasuk penelitian dengan menggunakan metode kualitatif, sedangkan penelitian yang menggunakan metode kuantitatif sebanyak 34 artikel. Table 5 di atas menunjukkan beberapa penelitian yang menggunakan metode kualitatif. Jurnal paling banyak menerbitkan penelitian kualitatif adalah di jurnal JAMAL dan Jurnal Tata Kelola \& Akuntabilitas Keuangan Negara. Jurnal

lainya yang pernah menerbitkan penelitian akuntabilitas pemerintah dengan menggunakan metode kualitatif adalah jurnal Integritas, Jurnal Akuntansi dan Auditing Indonesia, Jurnal Dinamika Akuntansi, dan Jurnal Media Riset Akuntansi, Auditing \& Informasi. Table 6 menunjukkan beberapa penelitian yang menggunakan metode kuantitatif. Jurnal paling banyak menerbitkan penelitian kualitatif adalah di jurnal JAAI dan JAB. Melihat jumlah penelitian kualitatif

yang sangat minim ini memberikan kemungkinan bagi penelitian selanjutnya untuk dapat menggunakan pendekatan ini. Ini juga dapat menjadi petunjuk bagi peneliti yang akan mencari penelitian akuntansi pemerintahan di jurnal tersebut.

Dari 11 artikel penelitian kualitatif, penulis mengklasifikasikan kembali berdasarkan metode penelitian yang digunakan seperti pada Table 7. Paling banyak metode yang digunakan adalah secara deskriptif atau studi kasus pada objek tertentu dan menggunakan metode konseptual. Metode

lain yang digunakan adalah metode dokumentasi, meta analisis dan fenomenologi. Table 8 menunjukan metode penelitian yang digunakan pada penelitian kuantitatif. Paling

banyak metode analisis yang digunakan adalah analisis regresi berganda sebanyak $88 \%$. Sebanyak $12 \%$ didominasi dengan menggunakan alat analisis uji beda dan statistik deskriptif. Masih banyak metode kuantitatif atau analisis statistik yang dapat digunakan oleh penelitian selanjutnya, misalnya pengujian data panel, logistik regresi dan lain-lain. Selain itu masih jarang peneliti sebelumnya yang melakukan mixed method antara metode kualitatif dan metode kuantitatif. Ini dapat menjadi peluang bagi penelitian selanjutnya untuk dapat mengisi gap penelitian yang ada.

\section{Klasifikasi Artikel Berdasarkan Metode Penelitian}

Berdasarkan pada metode penelitian yang dilakukan untuk meneliti akuntansi pemerintah di Indonesia ada dua kelompok yaitu penelitian kuantitatif dan penelitian kualitatif. Jumlah artikel kedua kelompok secara rinci dapat dilihat pada $\underline{\text { Table } 5}$ dan Table 6 sebagai berikut:

[Table 5. about here]

Dari 45 artikel terdapat 11 artikel yang termasuk penelitian dengan menggunakan metode kualitatif, sedangkan penelitian yang menggunakan metode kuantitatif sebanyak 34 artikel. Table 5 di atas menunjukkan beberapa penelitian yang menggunakan metode kualitatif. Jurnal paling banyak menerbitkan penelitian kualitatif adalah di jurnal JAMAL dan Jurnal Tata Kelola \& Akuntabilitas Keuangan Negara. Jurnal 
lainya yang pernah menerbitkan penelitian akuntabilitas pemerintah dengan menggunakan metode kualitatif adalah jurnal Integritas, Jurnal Akuntansi dan Auditing Indonesia, Jurnal Dinamika Akuntansi, dan Jurnal Media Riset Akuntansi, Auditing \& Informasi. Table 6 menunjukkan beberapa penelitian yang menggunakan metode kuantitatif. Jurnal paling banyak menerbitkan penelitian kualitatif adalah di jurnal JAAI dan JAB. Melihat jumlah penelitian kualitatif yang sangat minim ini memberikan kemungkinan bagi penelitian selanjutnya untuk dapat menggunakan pendekatan ini. Ini juga dapat menjadi petunjuk bagi peneliti yang akan mencari penelitian akuntansi pemerintahan di jurnal tersebut.

Dari 11 artikel penelitian kualitatif, penulis mengklasifikasikan kembali berdasarkan metode penelitian yang digunakan seperti pada Table 7. Paling banyak metode yang digunakan adalah secara deskriptif atau studi kasus pada objek tertentu dan menggunakan metode konseptual. Metode lain yang digunakan adalah metode dokumentasi, meta analisis dan fenomenologi. Table 8 menunjukan metode penelitian yang digunakan pada penelitian kuantitatif. Paling banyak metode analisis yang digunakan adalah analisis regresi berganda sebanyak $88 \%$. Sebanyak $12 \%$ didominasi dengan menggunakan alat analisis uji beda dan statistik deskriptif. Masih banyak metode kuantitatif atau analisis statistik yang dapat digunakan oleh penelitian selanjutnya, misalnya pengujian data panel, logistik regresi dan lain-lain. Selain itu masih jarang peneliti sebelumnya yang melakukan mixed method antara metode kualitatif dan metode kuantitatif. Ini dapat menjadi peluang bagi penelitian selanjutnya untuk dapat mengisi gap penelitian yang ada.

\section{[Table 6. about here]}

[Table 7. about here]

\section{[Table 8. about here]}

Table 9 menunjukkan sebaran artikel yang didasarkan pada sampel yang digunakan baik penelitian kuantitatif maupun penelitian kualitatif. Pada tabel dapat dilihat bahwa sampel paling banyak digunakan adalah beberapa pemerintah daerah sebanyak $46 \%$, sedangkan $26 \%$ untuk sampel studi kasus pada pemerintah daerah tertentu, $14 \%$ literatur dari beberapa artikel sedangkan lainnya menggunakan sampel pemerintah pusat, DPRD, BPK dan lain-lain. Penelitian selanjutnya dapat meneliti sampel lainnya misalnya pemerintah desa, DPRD, auditor pemerintah yang masih belum menjadi perhatian.

\section{[Table 9. about here]}

\section{KESIMPULAN}

Berdasarkan pada penelusuran artikel pada jurnal akreditasi minimal sinta 2 diperoleh 45 artikel yang membahas tentang akuntansi pemerintahan yang diterbitkan oleh 9 jurnal akreditasi. Kesimpulan yang dapat diambil dari artikel ini adalah : pertama, mayoritas penelitian tentang akuntansi pemerintahan di Indonesia diterbitkan di yaitu JAAI dan JAB masing-masing sebesar 20\%, sementara MRAAI 11 $\%$ dan JAMAL $16 \%$. Kedua, 11 artikel yang termasuk penelitian dengan menggunakan metode kualitatif, sedangkan penelitian yang menggunakan metode kuantitatif sebanyak 34 artikel. Ketiga, selama 10 tahun metode penelitian yang banyak digunakan oleh penelitian kualitatif dengan alat analisis deskriptif atau studi kasus pada objek tertentu dan menggunakan metode konseptual. Keempat, pada penelitian kuantitatif tentang akuntansi pemerintah di Indonesia, metode yang sering digunakan adalah analisis regresi. Artikel ini memiliki beberapa keterbatasan, pertama masih banyak beberapa artikel yang tidak dapat dijangkau secara online. Kedua, penelitian ini menggunakan software sederhana (Microsoft Excel). Penelitian selanjutnya dapat menyempurnakan pendekatan penelitian ini agar lebih sempurna.

\section{REFERENCES}

Abdullah, Syukriy, Mirza Khairul Reza, Afrah Junita, and Tuti Meutia. 2020. Parliament Oversight on Local Government Financial Management an Empirical Evidence. Riset Akuntansi dan Keuangan Indonesia 5(3): 296312. http://journals.ums.ac.id/index.php/reaksi/index\%0AParliament.

Adi, Priyo Hari, and Eviniar Nugraheni. 2020. Faktor-Faktor Yang Mempengaruhi Kinerja Keuangan Pemerintah Daerah: Studi Meta-Analisis. Media Riset Akuntansi, Auditing \& Informasi 20(1): 19.

Afdalia, Nadhira, Grace T. Pontoh, and Kartini. 2014. Theory of Planned Behavior Dan Readiness for Change Dalam Memprediksi Niat Implementasi Peraturan. Jaai 18(2): 110-23.

Afriyanti, Dwi, Harpanto Guno Sabanu, and Fahrizal Noor. 2018. Penilaian Indeks Akuntabilitas Instansi Pemerintah. Jurnal Tata Kelola dan Akuntabilitas Keuangan Negara: 21-42.

Ahyaruddin, Muhammad, and Rusdi Akbar. 2017. Akuntabilitas Dan Kinerja Instansi Pemerintah: Semu Atau Nyata? Jurnal Akuntansi \& Auditing Indonesia 12(2): 105-17.

Alhajjriana, Gusti Indira, Wahyudin Nor, and Rano Wijaya. 2018. Faktor-Faktor Yang Mempengaruhi Internet Financial Reporting Pemerintah Daerah Dan Implikasinya Terhadap Akuntabilitas Laporan Keuangan Daerah. Jurnal Akuntansi dan Bisnis 17(2): 100.

Atik Andhayani. 2017. Dilema Akrualisasi Akuntansi Dalam Pengelolaan Keuangan Daerah. Jurnal Akuntansi Multiparadigma (48): 291-307.

Arifin, Johan, Greg Tower, and Stacey Porter. 2013. Fiscal Policy Disclosure in Indonesian Local Governments. Jurnal Akuntansi \& Auditing Indonesia 17(1): 13-30. 2015.

Atmaja, RM Syah Arief, and Agung Nur Probohudono. 2015. Analisis Audit BPK RI Terkait Kelemahan SPI, Temuan Ketidakpatuhan Dan Kerugian Negara. INTEGRITAS Jurnal Anti Korupsi 1(1): 81-110.

Budiarto, Dekeng Setyo, and Devi Damayanti. 2020. Pengujian Struktural Pada Komitmen Manajemen, Transparansi Dan Akuntabilitas Pemerintah Daerah. Jurnal Akuntansi dan Bisnis 20(1): 17.

Christiaens, J., and Van Peteghem, V., 2007. Governmental accounting reform: Evolution of the implementation in Flemish municipalities. Finance. Account Manag. 23 (4): 375-399.

Christiaens, J., Vanhee, C., Manes-Rossi, F., Aversano, N., van Cauwenberge, P., 2015. The effect of IPSAS on reforming governmental financial reporting: An international comparison. Int. Rev. Adm. Sci. 81 (1): 158-177.

Christofzik, Désirée I. 2019. Does Accrual Accounting Alter Fiscal Policy Decisions? - Evidence from Germany. European Journal of Political Economy 60(July): 1805.

Eveline, Franta. 2017. Pengaruh Sap Berbasis Akrual, Sistem Informasi Akuntansi, Kualitas Sdm, Pengendalian Internal Dan Komitmen Organisasi Terhadap Kualitas Laporan Keuangan Di Badan Nasional Penanggulangan Bencana. Media Riset Akuntansi, Auditing dan Informasi 16(1): 1.

Habiby, Abdullah Lathif Elbaaqy, and Irwan Taufiq Ritonga. 2020. Analysis of Compliance and Audit Opinion, Correlation and Causes of Failure in Detecting Non Compliance: A Study on Local Government. Riset Akuntansi dan Keuangan Indonesia 5(2): 102-20.

Hadi, Waskito. 2017. Pengaruh Earning Performance Dan Proporsi Pad Lkpd 2015 Terhadap Kemandirian Daerah Di Jawa Tengah. Jurnal Tata Kelola dan Akuntabilitas Keuangan Negara: 1-20. 
Hakim, Lutfi, and Teguh Iman Maulana. 2019. Efektivitas Integrated Financial Management and Information System (IFMIS) Pada Proses Pelaporan Keuangan Pemerintah Pusat. Jurnal Akuntansi dan Bisnis 19(1): 80.

Hammam, Muhammad. 2017. Perjalanan Akuntansi Aset Tetap Pada Pemerintah Daerah Di Indonesia Dan Capital Charging Sebagai Wacana Pengembangannya.” Jurnal Tata Kelola \& Akuntabilitas Keuangan Negara 3(1): 21-32.

Hardiningsih, Pancawati, Indira Januarti, Ceacilia Srimindarti, and Rachmawati Meita Oktaviani. 2019. Does the Characteristics of Regional Government and Complexity Affect on the Disclosure Regional Financial Statements? Jurnal Akuntansi \& Auditing Indonesia 23(2): 106-16.

Harun, Harun, and Peter Robinson. 2010. 10 Research in Accounting in Emerging Economies The Adoption of Accrual Accounting in the Indonesian Public Sector. Elsevier. http://dx.doi.org/10.1108/S14793563(2010)0000010014

Hesford, J. W., Lee, S. S., Stede, W. A. V. d., \& Young, S. M. (Eds.). (2007). Management accounting: A bibliographic study (Vol. 1). The Netherlands:

Elsevier

Illahi, Beni Kurnia, and Muhammad Ikhsan Alia. 2017. Pertanggungjawaban Pengelolaan Keuangan Negara Melalui Kerja Sama BPK Dan KPK. Integritas 3(2): 37.

Inayattulloh, Muhammad Ramdhan, and Dodik Siswantoro. 2020. The Effect of Budget Management Quality and Internal Audit to Financial Statement Quality in the Ministries and Agencies. Jurnal Akuntansi dan Bisnis 19(2): 218.

Indriani, Andini, and Hermi Hermi. 2020. Faktor Yang Mempengaruhi Keuangan Daerah. Media Riset Akuntansi, Auditing \& Informasi 20(1): 99.

Istiyanto, Sigit. 2016. Kerugian Daerah, Kesejahteraan Masyarakat Dan Opini Pemeriksaan Atas LKPD Di Indonesia. Jurnal Akuntansi dan Bisnis 16(2): $135-48$.

Juwita, Rukmi. 2013. Pengaruh Implementasi Standar Akuntansi Pemerintahan Dan Sistem Informasi Akuntansi Terhadap Kualitas Laporan Keuangan. Trikonomika 12(2): 201.

Kamela, Hurian, and Dyah Setyaningrum. 2020. Do Political Factors Affect Financial Performance in Public Sector? Riset Akuntansi dan Keuangan Indonesia 5(2): 202-9.

Kurrohman, Taufik. 2013. Evaluasi Penganggaran Berbasis Kinerja Melalui Kinerja Keuangan Yang Berbasis. Jurnal Dinamika Akuntansi 5(1): 1-11.

Muhtar, Muhtar, Deni Ariyanto Putro, and Sutaryo Sutaryo. 2017. Determinants of Local Government Transparency: A Study on Local Government in Indonesia. Jurnal Akuntansi \& Auditing Indonesia 12(2): 141-56.

Nugraheni, Ayu Candra, and Henny Murtini. 2015. Determinan Kinerja Manajerial SKPD Kabupaten Banjarnegara. Jurnal Dinamika Akuntansi 7(2): 129-38.

Pahlevi, Agus Reza, and Doddy Setiawan. 2017. Apakah Karakteristik Kepala Daerah Berdampak Terhadap Kinerja Pemerintahan? Jurnal Akuntansi Multiparadigma 8(3): 427-611.

Purbasari, Heppy, and Andy Dwi Bayu Bawono. 2017. Pengaruh Desentralisasi Fiskal, Sistem Pengendalian Internal Dan Kinerja Pemerintah Daerah Terhadap Akuntabilitas Laporan Keuangan. Riset Akuntansi dan Keuangan Indonesia 2(2): 102-8.

Puspa, Dwi Fitri, and Riky Agung Prasetyo. 2020. Pengaruh Kompetensi Pemerintah Desa, Sistem Pengendalian Internal, Dan Aksesibilitas Laporan Keuangan Terhadap Akuntabilitas Pengelolaan Dana Desa. Media Riset Akuntansi, Auditing \& Informasi 20(2): 281.

Rahayu, Fitria Ika Siwi, and Fidiana Fidiana. 2018. Derterminan Kualitas Opini Audit Pemerintah Daerah. Jurnal Akuntansi Multiparadigma 9(2): 267-78.

Rahmanti, Virginia Nur, and Arum Prastiwi. 2011. Analisis Faktor-Faktor Yang Menyebabkan LKPD Beropini DIsclaimer. Jurnal Akuntansi Multiparadigma 2(2): 201-16.

Ritonga, Irwan Taufiq, and Syamsul Syahrir. 2016. Mengukur Transparansi Pengelolaan Keuangan Daerah Di Indonesia: Berbasis Website. Jurnal Akuntansi \& Auditing Indonesia 20(2): 110-26.

Saputra, Dany Adi, Lina Nur Ardila, Purnama Siddi, and Bambang Sutopo. 2018. "Financial Characteristics, Human Development Index, and Performance: A Study of Local Governments in Indonesia. Jurnal Akuntansi \& Auditing Indonesia 22(2): 94-104.

Setiono, Bambang, and Dody Hapsoro. 2016. Jurnal Akuntansi \& Auditing Indonesia. Jurnal Akuntansi \& Auditing Indonesia 20(1).

Purnama Siddi. 2016. Peran Karakteristik Keuangan Dan Opini Audit Dalam Meningkatkan Kinerja Penyelenggaraan Pemerintahan Daerah. Jurnal
Akuntansi Multiparadigma.
Stanislaus, Ratna Ayu Damayanti, and Syamsuddin. 2017. Pemaknaan Efisiensi Belanja Daerah Dalam Interpretative Phenomenological Analysis : Sebuah Konstruksi Atas Pemufakatan Para Agen. volume 3 nomor 2 INTEGRASI 3: $183-202$.

Surepno. 2015. Kunci Sukses Dan Peran Strategi Implementasi Akuntansi Berbasis Akrual.” Jurnal Dinamika Akuntansi 7(2): 119-28.

Syamsul, Syamsul. 2020. Potret Transparansi Pengelolaan Keuangan Daerah (Tpkd) Di Indonesia. Media Riset Akuntansi, Auditing \& Informasi 20(2): 185.

Taufik, Muchamad Ghufron, and Bandi. 2015. Karakteristik Pemda, Karakteristik Kepala Daerah, Inspektorat Dan Ketepatan Wwaktu Penyampaian LKPD Indonesia.” Jurnal Akuntansi dan Bisnis 15(1): 33-37.

Tresnawati, Eka Findi, and Achdiar Redy Setiawan. 2013. Ada Apa Dengan SAP (AADS) Akrual?. Jurnal Akuntansi Multiparadigma 4(2): 198-215.

Trisaptya, Yulia, Halim Dedy Perdana, and Sulardi. 2016. Evaluasi Akuntabilitas Laporan Keuangan Pemerintah Daerah Di Indonesia. Jurnal Akuntansi Dan Bisnis 16(1): 75-86.

Utami, Shafira Ramadhia, and Sulardi Sulardi. 2020. Pengaruh Karakteristik

Pemerintah Daerah, Opini Audit, Dan Rasio Kemandirian Terhadap Pengungkapan Laporan Keuangan Pemerintah Daerah. Jurnal Akuntansi dan Bisnis 19(2): 253.

Wulandari, Indriyani, and Bandi Bandi. 2015. Pengaruh E-Government, Kapabilitas Apip Dan Persentasi Penyelesaian Tindak Lanjut Terhadap Opini Audit Laporan Keuangan Pemerintah Daerah Di Indonesia. Jurnal Akuntansi dan Bisnis 15(2): 148.

Yuwana, Wirawan Purwa, Ali Djamhuri, and Wuryan Andayani. 2016. Analisis Atas Pengakuan Pendapatan Pajak Dan Migas Saat Permulaan Implementasi Basis Akrual Pada Akuntansi Pemerintah Pusat. Jurnal Tata Kelola dan Akuntabilitas Keuangan Negara: 71-88.

Conflict of Interest Statement: The authors declare that the research was conducted in the absence of any commercial or financial relationships that could be construed as a potential conflict of interest.

Copyright (C) 2022 and. This is an open-access article distributed under the terms of the Creative Commons Attribution License (CC BY). The use, distribution or reproduction in other forums is permitted, provided the original author(s) and the copyright owner(s) are credited and that the original publication in this journal is cited, in accordance with accepted academic practice. No use, distribution or reproduction is permitted which does not comply with these terms. 


\section{LIST OF TABLES}

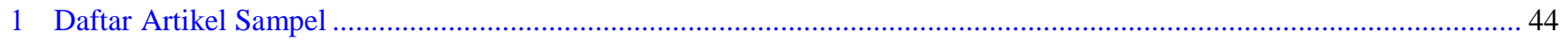

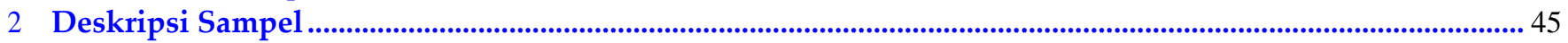

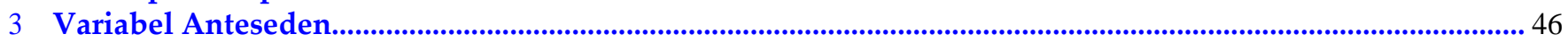

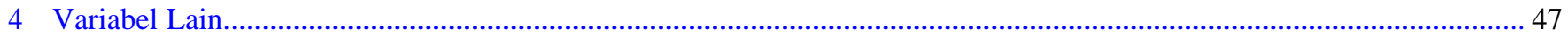

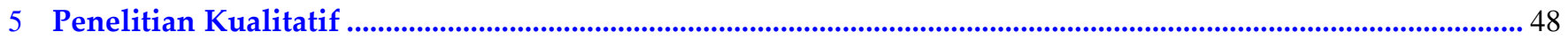

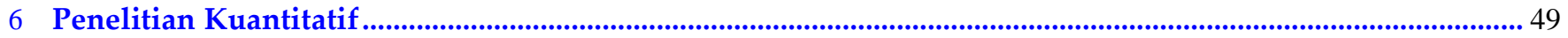

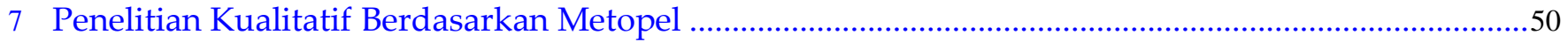

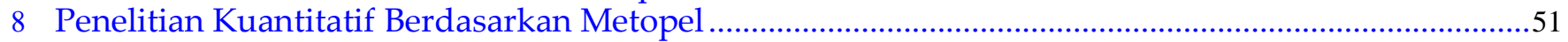

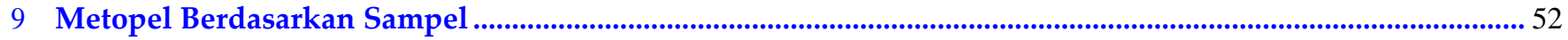




\begin{tabular}{|c|c|c|c|}
\hline No & Nama Jurnal & Tahun & Penulis \\
\hline 1 & Integritas & 2017 & (Illahi and Alia 2017) \\
\hline 2 & Integritas & 2017 & (Stanislaus, Damayanti, and Syamsuddin 2017) \\
\hline 3 & Integritas & 2015 & (Atmaja and Probohudono 2015) \\
\hline 4 & JAAI & 2013 & (Arifin, Tower, and Porter 2013) \\
\hline 5 & JAAI & 2014 & $\underline{\text { (Afdalia, Pontoh, and Kartini 2014) }}$ \\
\hline 6 & JAAI & 2015 & (Arifin, Tower, and Porter 2015) \\
\hline 7 & JAAI & 2016 & (Setiono and Hapsoro 2016) \\
\hline 8 & JAAI & 2016 & (Ritonga and Syahrir 2016) \\
\hline 9 & JAAI & 2017 & (Ahyaruddin and Akbar 2017) \\
\hline 10 & JAAI & 2017 & (Muhtar, Putro, and Sutaryo 2017) \\
\hline 11 & JAAI & 2018 & (Saputra et al. 2018) \\
\hline 12 & JAAI & 2019 & $\underline{\text { (Hardiningsih et al. 2019) }}$ \\
\hline 13 & $\mathrm{JAB}$ & 2015 & (Taufik and Bandi 2015) \\
\hline 14 & $\mathrm{JAB}$ & 2015 & (Wulandari and Bandi 2015) \\
\hline 15 & $\mathrm{JAB}$ & 2016 & (Trisaptya, Halim Dedy Perdana, and Sulardi 2016) \\
\hline 16 & $\mathrm{JAB}$ & 2016 & (Istiyanto 2016) \\
\hline 17 & $\mathrm{JAB}$ & 2017 & (Alhajjiriana, Nor, and Wijaya 2018) \\
\hline 18 & $\mathrm{JAB}$ & 2019 & $\underline{\text { (Hakim and Maulana 2019) }}$ \\
\hline 19 & $\mathrm{JAB}$ & 2018 & (Inayattulloh and Siswantoro 2020) \\
\hline 20 & $\mathrm{JAB}$ & 2019 & $\underline{\text { (Utami and Sulardi 2020) }}$ \\
\hline 21 & $\mathrm{JAB}$ & 2020 & $\underline{\text { (Budiarto and Damayanti 2020) }}$ \\
\hline 22 & Trikonomika & 2013 & (Juwita 2013) \\
\hline 23 & RAKI & 2017 & (Purbasari and Bawono 2017) \\
\hline 24 & RAKI & 2020 & (Kamela and Setyaningrum 2020) \\
\hline 25 & RAKI & 2020 & (Abdullah et al. 2020) \\
\hline 26 & RAKI & 2020 & (Habiby and Ritonga 2020) \\
\hline 27 & MRA & 2016 & (Eveline 2017) \\
\hline 28 & MRA & 2020 & $\underline{\text { (Adi and Nugraheni 2020) }}$ \\
\hline 29 & MRA & 2020 & $\underline{(\text { Indriani and Hermi 2020) }}$ \\
\hline 30 & MRA & 2020 & $\underline{(\text { Syamsul 2020) }}$ \\
\hline 31 & MRA & 2020 & (Puspa and Prasetyo 2020) \\
\hline 32 & JTKAKN & 2015 & (Afriyanti, Sabanu, and Noor 2018) \\
\hline 33 & JTKAKN & 2016 & (Yuwana, Djamhuri, and Andayani 2016) \\
\hline 34 & JTKAKN & 2017 & $\underline{(\text { Hadi 2017) }}$ \\
\hline 35 & JTKAKN & 2017 & $\underline{\text { (Hammam 2017) }}$ \\
\hline 36 & JDA & 2013 & $\underline{\text { (Kurrohman 2013) }}$ \\
\hline 37 & JDA & 2015 & (Surepno 2015) \\
\hline 38 & JDA & 2015 & (Nugraheni and Murtini 2015) \\
\hline 39 & JAMAL & 2011 & $\underline{\text { (Rahmanti and Prastiwi 2011) }}$ \\
\hline 40 & JAMAL & 2013 & (Tresnawati and Setiawan 2013) \\
\hline 41 & JAMAL & 2016 & (Siddi 2016) \\
\hline 42 & JAMAL & 2017 & (Andhayani 2017) \\
\hline 43 & JAMAL & 2017 & $\underline{\text { (Pahlevi and Setiawan 2017) }}$ \\
\hline 44 & JAMAL & 2018 & (Rahayu and Fidiana 2018) \\
\hline 45 & JAMAL & 2018 & (Ahyaruddin and Amrillah 2018) \\
\hline
\end{tabular}




\begin{tabular}{rlcc}
\hline No & Nama Jurnal & Jumlah & \% \\
1 & Integritas & 3 & 0,07 \\
2 & Jurnal Akuntansi dan Auditing Indonesia & 9 & 0,20 \\
3 & Jurnal Akuntansi dan Bisnis & 9 & 0,20 \\
4 & Trikonomika & 1 & 0,02 \\
5 & Riset Akuntansi dan Keuangan Indonesia & 4 & 0,09 \\
& Jurnal Media Riset Akuntansi, Auditing \& & & \\
6 & Informasi & 5 & 0,11 \\
& Jurnal Tata Kelola \& Akuntabilitas Keuangan & 4 & 0,09 \\
7 & Negara & 3 & 0,07 \\
8 & Jurnal Dinamika Akuntansi & 7 & 0,16 \\
9 & Jurnal Akuntansi Multiparadigma & 45 & 1,00 \\
\hline & Total & & \\
\hline
\end{tabular}




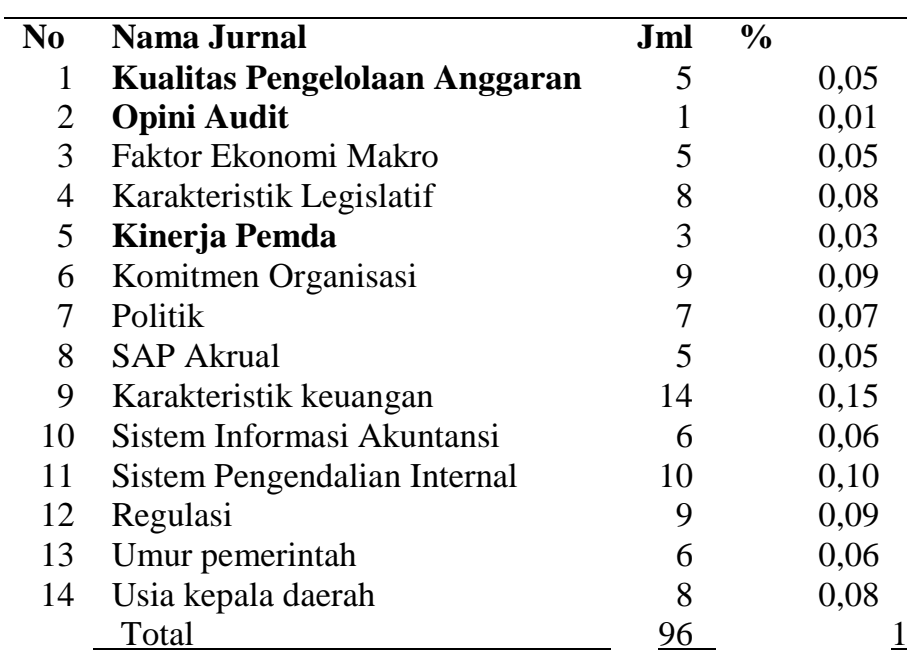


TABLE 4 / Variabel Lain

Variabel Anteseden Jumlah Prosentase

Transparansi dan Akuntabilitas Publik

Fraud

\begin{tabular}{cc} 
Jumlah & Prosentase \\
1 & 0.50 \\
1 & $\underline{0.50}$ \\
\hline
\end{tabular}




\begin{tabular}{rlrc} 
No & Nama Jurnal & Jumlah & Prosentase \\
1 & Integritas & 2 & 0,18 \\
2 & Jurnal Akuntansi dan Auditing Indonesia & 1 & 0,09 \\
3 & Jurnal Akuntansi Multiparadigma & 3 & 0,27 \\
4 & Jurnal Dinamika Akuntansi & 1 & 0,09 \\
5 & Jurnal Tata Kelola \& Akuntabilitas Keuangan Negara & 3 & 0,27 \\
6 & Jurnal Media Riset Akuntansi, Auditing \& Informasi & 1 & 0,09 \\
& Total & 11 & 1,00 \\
\hline
\end{tabular}




\begin{tabular}{clrc}
\hline No & Nama Jurnal & Jumlah & Prosentase \\
1 & Integritas & 1 & 0,03 \\
& Jurnal Tata Kelola \& Akuntabilitas Keuangan & 2 & 0,06 \\
2 & Negara & 1 & 0,03 \\
3 & Trikonomika & 2 & 0,06 \\
4 & Jurnal Dinamika Akuntansi & 3 & 0,09 \\
5 & Riset Akuntansi dan Keuangan Indonesia & 4 & 0,12 \\
6 & Jurnal Akuntansi Multiparadigma & 4 & 0,12 \\
7 & Jurnal Media Riset Akuntansi, Auditing \& & 8 & 0,24 \\
8 & Informasi & 9 & 0,26 \\
9 & Jurnal Akuntansi dan Auditing Indonesia & 34 & 1,00 \\
\hline
\end{tabular}


TABLE 7 / Penelitian Kualitatif Berdasarkan Metode Penelitian

\begin{tabular}{clrc}
\hline No & Metode & Jumlah & Prosentase \\
1 & Deskriptif/studi kasus & 5 & 0,45 \\
2 & Dokumen dan berita & 1 & 0,09 \\
3 & Fenomenologi transendental, sosial, dan hermeneutika-ontologi & 1 & 0,09 \\
4 & Meta-analisis & 1 & 0,09 \\
5 & Konseptual & 3 & 0,27 \\
& Total & 11 & 1,00 \\
\hline
\end{tabular}


TABLE 8 / Penelitian Kuantitatif Berdasarkan Metode Penelitian

\begin{tabular}{|c|c|c|c|}
\hline No & Metode & Jml & Prosentase \\
\hline 1 & Deskripsi statistik & 2 & 0,06 \\
\hline 2 & regresi & 30 & 0,88 \\
\hline 3 & uji beda & 2 & 0,06 \\
\hline & Total & $\underline{34}$ & $\underline{1,00}$ \\
\hline
\end{tabular}




\begin{tabular}{clr}
\hline No & Sampel & Jumlah \\
1 & Pemerintah Pusat & 0,09 \\
2 & Pemerintah Daerah & 0,46 \\
3 & Studi Kasus Pemda Tertentu & 0,26 \\
4 & Literature Review (konseptual) & 0,14 \\
5 & Lain-Lain (DPRD, BPK) & 0,06 \\
& Total & $\underline{1,00}$ \\
\cline { 2 - 3 }
\end{tabular}

